\title{
The effect of the aqueous extract Peumus boldus on the proliferation of hepatocytes and liver function in rats submitted to expanded hepatectomy ${ }^{1}$
}

\author{
Maria Bernadete Galrão de Almeida FigueiredoI, Vanessa Rocha de Santana ${ }^{I I}$, Maria Júlia NardelliII, Matheus de Souza

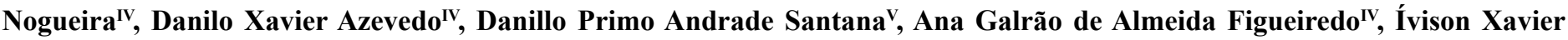 \\ Duarte $^{\mathrm{VI}}$, Ricardo Luiz Cavalcanti de Albuquerque Junior ${ }^{\mathrm{VII}}$, Sônia Oliveira Lima ${ }^{\mathrm{VII}}$
}

DOI: http://dx.doi.org/10.1590/S0102-865020160090000006

IMaster, Postgraduate Program in Health and Environment, Department of Morphology and Structural Biology, Universidade Tiradentes (UNIT), Aracaju-SE, Brazil. Scientific and intellectual content of the study; conception and design of the study; acquisition, analysis and interpretation of data; technical procedures; statistical analysis; manuscript preparation and writing.

"Master, Fellow PhD degree, Postgraduate Program in Health and Environment, Department of Morphology and Structural Biology, UNIT, AracajuSE, Brazil. Scientific and intellectual content of the study, conception and design of the study, analysis and interpretation of data.

IIIMaster, Veterinary Medicine, Universidade Federal de Campina Grande (UFCG), Campina Grande-PB, Brazil. Technical procedures.

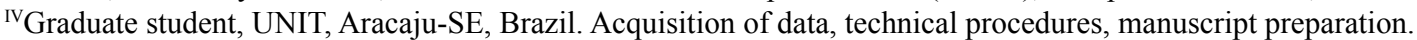

${ }^{v}$ Graduate student, Universidade Federal Aracaju-SE, Brazil. Acquisition of data, technical procedures, manuscript preparation.

${ }^{v}$ Pathologist, UNIT, Aracaju-SE, Brazil. Histopathological examinations.

${ }^{V I I P h D}$, Full Professor, Department of Morphology and Structural Biology, ITP, UNIT, Aracaju-SE, Brazil. Scientific and intellectual content of the study; acquisition, analysis and interpretation of data; technical procedures; statistical analysis; manuscript writing, critical revision, final approval.

\section{ABSTRACT}

PURPOSE: To assess the effect of aqueous extract of Peumus Boldus (AEPB) on the liver proliferative response after parcial hepatectomy of $70 \%(\mathrm{PH})$ in rodents.

METHODS: Twenty Wistar rats were divided in two groups: AEPB100 (whose rats received 100mg/Kg of AEPB, once a day, orally, in 4 days prior to the first surgical procedure) and Vehicle (whose rats were treated similarly with distilled water). Both groups underwent PH. After 24 hours the remaining livers were removed for studying the proliferation of hepatocytes by Ki- 67 and $2 \mathrm{~mL}$ of blood were collected for serological assessment: cholesterol, glucose, triglycerides, aspartate aminotransferase, alanine aminotransferase, alkaline phosphatase, and total, direct and indirect bilirubin. All data were analyzed by Gaussian distribution. Statistically significant differences between mean values were analyzed using T Student's test. Non-Gaussian data were analyzed using Mann-Whitney's test.

RESULTS: The liver of all these rats presented positive staining of Ki-67, indicating liver proliferation. Laboratory results showed no significant difference in serum values between the analyzed groups. The analysis of Ki-67 was significantly more positive in AEPB100 group than in Vehicle group.

CONCLUSION: Aqueous extract of Peumus Boldus acute administration exerts significant positive effect on liver regeneration after $24 \mathrm{~h}$ in rats that underwent parcial hepatectomy, while maintaining unchanged hepatic function.

Key words: Plants, Medicinal. Hepatectomy. Hepatocytes. Cell Proliferation. Rats. 


\section{Introduction}

The liver parenchyma is quiescent and only a small percentage of cells is in the cell cycle division at any time. However, after chemical, viral and traumatic injury, hepatocytes are able to undergo a proliferative response in order to restore the lost parenchyma ${ }^{1}$. Liver proliferation is a compensatory hyperplasia process, which is driven more by functional than anatomical need ${ }^{2}$.

Operation on the liver is challenging because of its vital functions. Despite technical advances and high experience of liver resection of specialized centers, there are still relatively high rates of postoperative morbidity and mortality associated with posthepatectomy complications, including fever, hemorrhage, bile leakage, liver failure, pleural effusion, and subphrenic infection ${ }^{3}$. Therefore, depending on the severity of the hepatic injury and consequent hepatectomy, the time-course of liver restoration may be too long, which may lead to long-term hepatic deficiency ${ }^{4}$.

Many substances have been tried in partially hepatectomizated animals to improve liver regenerative process in rodent model $^{4}$ and herbal products appear as important alternatives in this search ${ }^{5,6}$. Although Brazil has a rich botanic variety and traditionally uses medicinal plants, including Peamus boldus, most of the time it is based only on the popular knowledge, with no pre-clinical or clinical evidence ${ }^{7}$.

Peumus boldus, popularly known as boldo, is found in official pharmacopoeia of Brazil, Chile, Germany, Spain, Portugal and Switzerland as a reference in treatment of liver diseases. Boldo is popularly used in cases of hepatitis, hepatic colic, biliary lithiasis and intestinal disorders, and rheumatism, poor digestion, asthenia, dyspepsia, inappetence and other disorders ${ }^{8}$. Studies have demonstrated that polar extracts of Peumus boldus are able to display antioxidant activity ${ }^{9}$ and reduce hepatic lipoperoxidation induced by cisplatin ${ }^{10-12}$.

Extracts of Peumus boldus obtained with polar solvents, like water, are rich in flavonoids, such as quercetin, kaempferol and isorhamnetin derivatives, as well as in alkaloids, such as boldine ${ }^{13}$. Boldine has proved to attenuate cholestasis associated with nonalcoholic fatty liver disease in high-sucrose diet-induced hereditary hypertriglyceridemy ${ }^{14}$ and enhance bile production via osmotic and farnesoid $\mathrm{X}$ receptor dependent mechanisms ${ }^{15}$ in rodent model. In addition, quercetin is able to regulate hepatic cholesterol metabolism mainly through the pathways that promote cholesterol-to-bile acid conversion and cholesterol efflux ${ }^{16}$ and reduce galactosamine/lipopolysaccharide-induced hepatotoxicity ${ }^{17}$.

As boldo and its chemical compounds have previously demonstrated beneficial properties on the Peumus boldus leaves ${ }^{8-12}$, the purpose of the current study is to assess the effect of aqueous extract of the Peumus Boldus on the liver proliferative response after hepatectomy in rodents.

\section{Methods}

Ethical principles of the COBEA (Brazilian College for Animal Experimentation) for experiments in animals were applied in this study, which was approved by the Ethical Committee for Animal Experimentation (approval 021114).

\section{Extract preparation}

Leaves of Peumus boldus (Farmácia Viva, Parque da Sementeira, Aracaju/SE, Brazil) were dried, weighed and grounded in electric mill until a fine-grained powder was obtained. Peumus boldus sample (20g) was extracted using distilled water (200 $\mathrm{mL}$ ) under constant stirring for 4 hours at $35^{\circ} \mathrm{C}$. After extraction, the mixture was filtered, lyophilised and stored at $5^{\circ} \mathrm{C}$. The dry extract was suspended in distilled water at $100 \mathrm{mg} / \mathrm{mL}$ for oral administration by gavage to the animals.

\section{Biological assay}

Twenty Novergicus albinus young male rats (8 weeks age), Wistar lineage, weighing $300+50 \mathrm{~g}$ were randomly assigned into two experimental groups: AEPB100 and Vehicle, with 10 rats each. The first received $100 \mathrm{mg} / \mathrm{Kg}$ of AEPB $(2 \mathrm{~mL})$, once a day, orally, 4 days prior to the first surgical procedure. The second was treated similarly with distilled water $(2 \mathrm{~mL})$. Animals were housed in plastic cages with wood-shavings bedding, which was replaced daily, under controlled temperature at $22 \pm 2^{\circ} \mathrm{C}$ and a 12-hr light/ dark regimen, with water and food (Labina; Purina, Sao Paulo, Brazil) ad libitum. The animals were subjected to dissociative anesthesia with intraperitoneal administration of $0.10 \mathrm{~mL} / 100 \mathrm{~g}$ of 10\% ketamine (Ketamine ${ }^{\circledR}$, Rhobifarma Ind. Ltd. Pharmaceutical.) and $0.25 \mathrm{~mL} / 100 \mathrm{mg}$ of xylazine (Anasedan ${ }^{\circledR}$ Purina Agribrands of Brazil Ltda.). After trichotomy and antisepsis with PvPi, the access to the peritoneal cavity of the animals was performed by median laparotomy, approximately $4 \mathrm{~cm}$ from the xiphoid appendix in caudal direction. The median and left lateral lobes of the liver (corresponding to $70 \%$ of the organ) were excised after clamping and ligating the narrow pedicle with a 3-0 cotton suture 5 . The abdomen was closed in two planes with continuous sutures 4-0 mononylon, the peritoneum and aponeurosis in deep planes and skin on a superficial plane. Surgical procedures were always 
performed at the same time, to avoid the influence of variations of the circadian cycle. After surgery, the rats were on a normal diet for the completely experimental period. Twenty-four hours later, when the peak of DNA synthesis occurs, animals underwent a new operation to remove the remaining liver.

\section{Biochemical analysis}

Before the second laparotomy, blood samples $(2 \mathrm{~mL})$ were collected from the inferior vena cava of all rats for serologic testing of hepatic functional status. The blood samples were centrifuged at $1000 \mathrm{rpm}$ for $10 \mathrm{~min}$ and serum was separated and analyzed by the biochromatic Kinetics technique, using the kit trademark Labtest Diagnostica SA (Belo Horizonte, MG, Brazil) in automatic device model (Dimension AR Date of Behring ${ }^{\circledR}$ ). The serum parameters analyzed in this study were aspartate aminotransferase (AST), alanine aminotransferase (ALT), alkaline phosphatase (ALP), gamma-glutanil transpetidase (GGT), total bilirubin (TB), direct bilirubin (BD), indirect bilirubin (BI), and albumin (ALB).

\section{Histological analysis}

Tissue specimens were fixed in buffered formaldehyde (10\%, pH 7.4) for $48 \mathrm{~h}$, decalcified in $5 \%$ nitric acid for $72 \mathrm{~h}$, dehydrated in increasing ethyl alcohol solutions, and diaphanized in xylol for inclusion in paraffin. Subsequently, ten histological sections ( $5 \mu \mathrm{m}$ thick) were obtained and stained in hematoxylineosin for analysis using a light microscope (Olympus CX31 optic microscope) by two trained observers. The morphological parameters suggestive of hepatic functional stress analyzed in this study were hydropic degeneration, steatosis, portal inflammation, parenchymatous inflammation and necrosis. The intensity of the morphological changes was assessed as follows: 0 (lack of morphological change); 1 (morphological changes affecting less than $10 \%$ of the hepatocytes); 2 (morphological changes affecting between $10 \%$ and $50 \%$ of the hepatocytes); and 3 (morphological changes affecting more than $50 \%$ of the hepatocytes).

\section{Liver regeneration analysis}

Liverregenerationwasevaluatedbyimmunohistochemical staining for Ki-67 antigen using monoclonal primary anti-Ki67 antibody (MIB-1, Dako, Glostrup, Denmark, 1:50) on $5 \mu \mathrm{m}$ thick histological sections obtained from the formalin-fixed and paraffin-embedded liver tissues. Sections were mounted on poly- L-lysine-coated glass slides, deparaffinized, rehydrated in an increasing alcohol series, placed in phosphatebuffered saline (PBS), and treated with $2 \%$ hydrogen peroxide in methanol for 15 min to block endogenous peroxidase activity. Subsequently, monoclonal primary antibody was incubated for $120 \mathrm{~min}$ at $25^{\circ} \mathrm{C}$. The sections were then incubated for $35 \mathrm{~min}$ with a biotinylated horse antimouse immunoglobulin. The reaction product was detected with an avidin-biotin-peroxidase complex and diaminobenzidine was used as a chromogen substrate. Positive and negative controls were used to assess and control the staining procedure. Sections were examined blindly at high power (x400), and 20 fields were chosen at random. Nuclear labeling indexes for Ki-67 (positive nuclei/total number of counted nuclei) were determined by evaluation of at least 1000 hepatocyte nuclei.

\section{Statistical analysis}

All data were first subjected to analysis of Gaussian distribution. Statistically significant differences between mean values presenting Gaussian distribution were analyzed using paired and unpaired T Student's test. Non-gaussian data were analyzed using Mann-Whitney's test. Differences between means were considered significant when $\mathrm{p}<0.05$.

\section{Results}

In this study, no significant difference was observed in the body weight of the animals in response to the treatment with $100 \mathrm{mg} / \mathrm{Kg}$ AEPB in comparison with the administration of distilled water (vehicle) (Table 1, $\mathrm{p}>0.05$ ).

TABLE 1 - Body weight of the animals subjected to $70 \%$ hepatectomy treated with vehicle and aqueous extract of Peumus boldus at $100 \mathrm{mg} / \mathrm{Kg}$.

\begin{tabular}{cccc}
\hline $\begin{array}{c}\text { Experimental } \\
\text { conditions }\end{array}$ & \multicolumn{2}{c}{ Body weight $(\mathrm{g})$} & $\begin{array}{c}\text { Two-tailed } \\
\text { P values }^{\mathrm{b}}\end{array}$ \\
\hline Pre surgery & $258.2 \pm 38.3$ & $271.1 \pm 16.9$ & 0.35 \\
Post-surgery & $236.7 \pm 33.7$ & $259.0 \pm 17.7$ & 0.08 \\
$\begin{array}{c}\text { Two-tailed P } \\
\text { values }^{\mathrm{a}}\end{array}$ & $<000.1$ & $<0.0001$ & \\
\hline
\end{tabular}

a Paired T Student's test; ${ }^{\mathrm{b}}$ Unpaired T Student's test

The hepatic regeneration index observed in the remaining liver weight after $24 \mathrm{~h}$ of $\mathrm{PH}$ was similar in both groups $(4.1 \pm 0.4 \mathrm{in}$ Vehicle vs 4.2 \pm 0.3 in AEPB100; $\mathrm{p}=0.49$ ).

The analysis of the livers of the animals at the first surgery revealed Gross features represented by smooth parenchyma, crumbly and dark reddish brown color, typical of the body with great blood supply, which were compatible with normality. 
However, over the course of the second surgery, the parenchyma of the remaining livers presented a yellowish appearance, consistent with fatty degeneration, likely because of surgical aggression by extended hepatectomy.

As shown in Table 2, no significant differences in the serum levels of cholesterol, glucose, triglycerides, aspartate aminotransferase, alanine aminotransferase, alkaline phosphatase, as well as in total, direct and indirect bilirubin, were observed between the groups treated with vehicle only and with AEPB at $100 \mathrm{mg} / \mathrm{Kg}$. This fact occurs, probably, because hepatocytes have the ability to keep active all the functions, while the proliferation.

TABLE 2 - Biochemical analysis of serum parameters of the animals subjected to $70 \%$ hepatectomy treated with vehicle and aqueous extract of Peumus boldus at $100 \mathrm{mg} / \mathrm{Kg}$.

\begin{tabular}{|c|c|c|c|c|c|}
\hline \multirow{2}{*}{$\begin{array}{c}\text { Serum } \\
\text { parameters }\end{array}$} & \multicolumn{2}{|c|}{ Vehicle } & \multicolumn{2}{|c|}{ AEPB 100} & \multirow{2}{*}{$\mathrm{P}_{\text {values }}^{\mathrm{a}}$} \\
\hline & Mean & SD & Mean & SD & \\
\hline $\begin{array}{l}\text { Glucose } \\
(\mathrm{mg} / \mathrm{dL})\end{array}$ & 114.56 & 35.68 & 134.13 & 24.66 & 0.486 \\
\hline $\begin{array}{l}\text { Total bilirubin } \\
(\mathrm{mg} / \mathrm{dL})\end{array}$ & 0.16 & 0.03 & 0.18 & 0.09 & 0.213 \\
\hline $\begin{array}{c}\text { Direct } \\
\text { bilirrubina } \\
(\mathrm{mg} / \mathrm{dL})\end{array}$ & 0.11 & 0.03 & 0.13 & 0.07 & 0.175 \\
\hline $\begin{array}{l}\text { Indirect } \\
\text { bilirrubina } \\
(\mathrm{mg} / \mathrm{dL})\end{array}$ & 0.05 & 0.03 & 0.06 & 0.04 & 0.533 \\
\hline $\begin{array}{l}\text { Triglycerides } \\
(\mathrm{mg} / \mathrm{dL})\end{array}$ & 25.89 & 15.21 & 46.63 & 63.13 & 0.584 \\
\hline $\begin{array}{l}\text { Cholesterol } \\
(\mathrm{mg} / \mathrm{dL})\end{array}$ & 46.33 & 11.83 & 52.38 & 14.59 & 0.588 \\
\hline $\begin{array}{c}\text { Alkaline } \\
\text { phosphatase } \\
(\mathrm{U} / \mathrm{L})\end{array}$ & 403.44 & 108.54 & 488.75 & 162.15 & 0.169 \\
\hline $\begin{array}{c}\text { aspartate ami- } \\
\text { notransferase } \\
(\mathrm{U} / \mathrm{L})\end{array}$ & 463.22 & 232.64 & 530.50 & 254.44 & 0.114 \\
\hline $\begin{array}{c}\text { alanine ami- } \\
\text { notransferase } \\
(\mathrm{U} / \mathrm{L})\end{array}$ & 444.89 & 163.10 & 525.38 & 213.61 & 0.383 \\
\hline
\end{tabular}

${ }^{a}$ Unpaired T Student's test.

After enlarged partial hepatectomy in rats treated with $\mathrm{EAPB}$ at $100 \mathrm{mg} / \mathrm{Kg}$, the mean scores of the pathological changes, concerning the hepatic histological architecture and cell morphology, suggestive of functional stress were found in both groups (Table 3). The cytoplasmic non-lipid vacuolation of the hepatocytes interpreted as hydropic degeneration was characterized by progressive loss of eosinophilia and displacement of cytoplasmic granules to the periphery, discrete cell ballooning and sometimes nuclear pyknosis (Figure 1A). No significant difference in the mean scores of hepatocyte ballooning consistent with hydropic degeneration between the groups $(\mathrm{p}=0.792)$. The lipid vacuolation, or macrovesicular steatosis, was characterized by intense pyknosis and nuclear eccentricity associated with intracytoplasmic vesicle formation, and round shaping of the hepatocytes (Figure 1B). The mean scores of lipid vacuolation (steatosis) were significantly lower in the group treated with EAPB at $100 \mathrm{mg} / \mathrm{Kg}$ than in the group treated with vehicle only $(\mathrm{p}=0.02)$. The periportal inflammatory reaction (Figure 1C) ranges from absent to moderate and was represented by occasional lymphocytes and polymorphonuclear neutrophils, whereas the intraparenchymatous inflammation (Figure 1D) was predominantly mild; however, no significant difference between groups ( $\mathrm{p}=0.195$ and $\mathrm{p}=0.495$, respectively). The apoptotic bodies, represented by homogeneous and eosinophilic globular structures, sometimes containing pyknotic nuclear remains inside, were uncommon in both groups, and no significant difference was observed between them $(\mathrm{p}=0.906)$. In general, areas of necrosis were focal, mostly affected small cell groups, and usually promoted discrete local inflammatory infiltration. Although no significant difference was observed between groups in the mean scores of necrosis, $20 \%$ of the animals belonging to the vehicle group presented approximately half of the remaining hepatic parenchyma affected by necrosis, whereas such extensive damage associated to necrotic areas were not found in the group treated with AEPB at $100 \mathrm{mg} / \mathrm{Kg}$.

TABLE 3 - Mean scores of liver pathological changes intensity in the experimental groups.

\begin{tabular}{|c|c|c|c|c|c|}
\hline \multirow[b]{2}{*}{$\begin{array}{c}\text { Pathological } \\
\text { parameters }\end{array}$} & \multicolumn{2}{|c|}{ Vehicle } & \multicolumn{2}{|c|}{ AEPB 100} & \multirow[b]{2}{*}{$\begin{array}{c}\mathrm{P} \\
\text { values }^{\mathrm{a}}\end{array}$} \\
\hline & $\begin{array}{c}\text { Mean } \pm \\
\text { SD }\end{array}$ & $\begin{array}{c}\text { Me- } \\
\text { dian } \\
(\min - \\
\max )\end{array}$ & $\begin{array}{c}\text { Mean } \\
\pm \\
\text { SD }\end{array}$ & $\begin{array}{l}\text { Mediana } \\
(\max - \\
\min )\end{array}$ & \\
\hline $\begin{array}{c}\text { Hydropic } \\
\text { vacuolation }\end{array}$ & $\begin{array}{l}2.8 \pm \\
0.41\end{array}$ & $\begin{array}{c}3 \\
(2-3)\end{array}$ & $\begin{array}{c}2.86 \pm \\
0.35\end{array}$ & $3(2-3)$ & 0.792 \\
\hline Steatosis & $\begin{array}{l}1.3 \pm \\
0.67\end{array}$ & $\begin{array}{c}1 \\
(0-2)\end{array}$ & $\begin{array}{c}0.56 \pm \\
0.63\end{array}$ & $0(0-2)$ & 0.020 \\
\hline $\begin{array}{l}\text { Portal in- } \\
\text { flammation }\end{array}$ & $\begin{array}{l}1.4 \pm \\
0.51\end{array}$ & $\begin{array}{c}1 \\
(1-2)\end{array}$ & $\begin{array}{c}1.00 \pm \\
0.53\end{array}$ & $1(0-2)$ & 0.145 \\
\hline $\begin{array}{l}\text { Parenchyma- } \\
\text { tous inflam- } \\
\text { mation }\end{array}$ & $\begin{array}{l}0.3 \pm \\
0.48\end{array}$ & $\begin{array}{c}0 \\
(0-1)\end{array}$ & $\begin{array}{c}0.53 \pm \\
0.51\end{array}$ & $1(0-1)$ & 0.495 \\
\hline Necrosis & $\begin{array}{l}1.1 \pm \\
1.10\end{array}$ & $\begin{array}{c}1 \\
(0-3)\end{array}$ & $\begin{array}{c}0.46 \pm \\
0.51\end{array}$ & $0(0-1)$ & 0.175 \\
\hline Apoptosis & $\begin{array}{l}0.9 \pm \\
0.31\end{array}$ & $\begin{array}{c}1 \\
(0-1)\end{array}$ & $\begin{array}{c}0.86 \pm \\
0.35\end{array}$ & $1(0-1)$ & 0.906 \\
\hline
\end{tabular}

a Mann-Whitney's test 

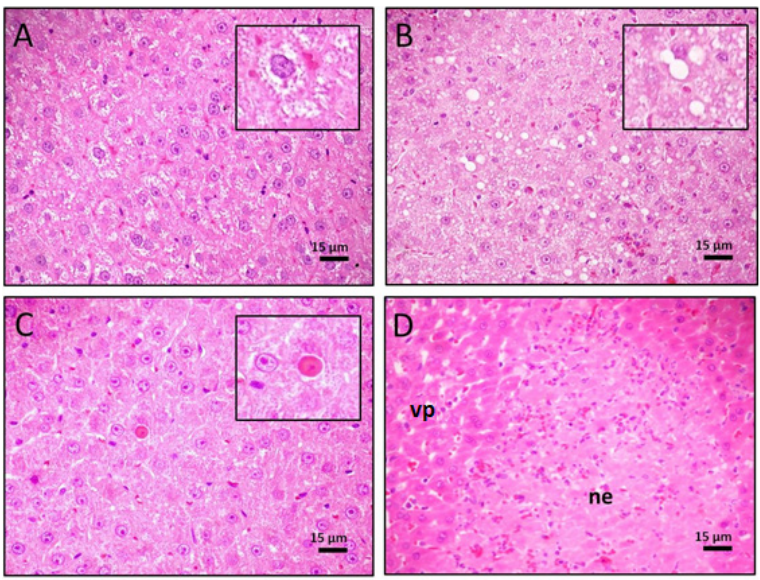

FIGURE 1 - Histological sections stained with hematoxylin/eosin (HE) showing the main pathological changes of the hepatic parenchyma and stroma observed in the experimental groups. (A) Non-lipid vacuolation compatible with hydropic degeneration in the group treated with AEPB (H\&E, x400). (B) Lipid vacuolization consistent with macrovesicular steatosis in an animal treated vehicle only (H\&E-x100). (C) Apoptotic body (H\&E, x400). (D) Necrosis area (ne) surrounded by viable parenchyma (VP) in s liver sample of animal treated AEPB and vehicle only, respectively (H\&E, x40).

In this study, immunoexpression of Ki-67 antigen was observed mainly in the nuclei of hepatocytes. As described Figure 2 , the proliferative index, expressed by the percentage mean of Ki67-positive cells in the remaining hepatic samples, was significantly higher in the group treated with AEPB at $100 \mathrm{mg} /$ $\mathrm{Kg}$ than in the one treated with vehicle only $(\mathrm{p}<0.0001$, Figure 3$)$.
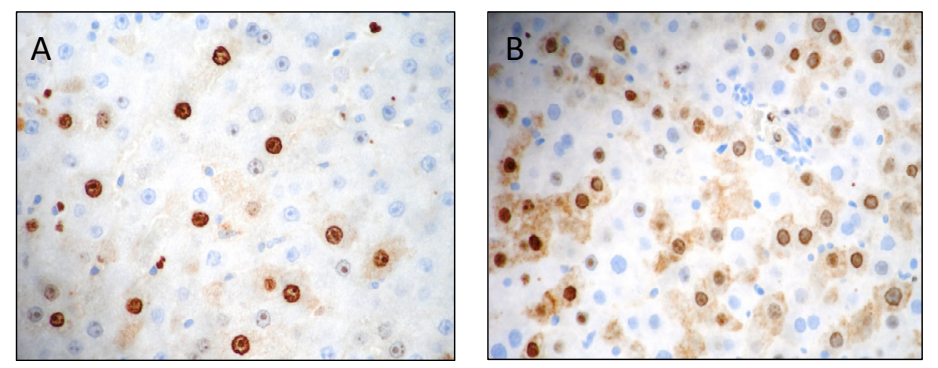

FIGURE 2 - Histological section of mouse liver tissue after $70 \%$ hepatectomy. A) Nuclear immunpositivity for the Ki-67 antigen in the group treated with vehicle only (distilled water). B) Intense and diffuse nuclear/cytoplasmic immunoexpression of $\mathrm{Ki}-67$ antigen in the group treated with AEPB at $100 \mathrm{mg} / \mathrm{Kg}(\mathrm{SABC}, \mathrm{x} 400)$.

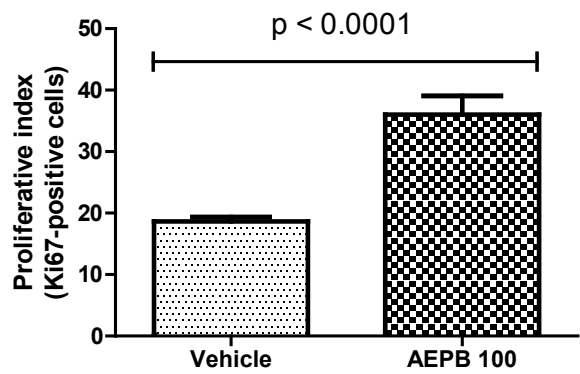

FIGURE 3 - Proliferative index of the remaining hepatic samples after $24 \mathrm{~h}$ of enlarged hepatectomy $(70 \%)$ in the experimental groups (T Student's test).

\section{Discussion}

The restoration of the liver weight after partial hepatectomy in humans appears to occur in two to three weeks and completes after three months ${ }^{17}$. Due to limitations in using human liver for studies on hepatic regeneration, most of the information on this process has been obtained from in vivo animal models (e.g. rats and mice) or with hepatic cells in culture (in vitro) ${ }^{18}$. Hepatic proliferative process in rats is similar to the proliferation of human liver, which explains its widespread use in many areas of biomedical research, such as endocrine, cellular, genetic and molecular ${ }^{19}$. We used rats in this research due to the low cost of acquisition and maintenance of the animals and because of their high resistance to infection and surgical trauma. We picked young animals as their age may compromise the partial post-hepatectomy regenerative response, and only male rats were used in attempt to mitigate the recognized influence of estrogen on the hepatic proliferation $^{20,21}$.

In this study, the use of leaves-derived aqueous extract of Peumus boldus was based on its phytochemical composition and biological effects. Studies have demonstrated the presence of more than 30 different compounds in Peumus boldus leaves. However, the therapeutic benefits of this plant are associated with benzoquinolíne alkaloids like boldine, isocordine, secoboldine and N-methylaurotetanine; flavonoids, particularly catechins and quercetin; and essential oils found in its leaves and husk ${ }^{22}$. Boldine is the principal alkaloid found in the leaves of boldo ${ }^{8}$. Its pharmacological activities, resulting from the antioxidant activity have been well described in the scientific literature ${ }^{10,23-25}$.

Previous studies have failed to demonstrate choleretic activity after oral administration of $200-800 \mathrm{mg} / \mathrm{kg}$ of aqueous ethanolic boldo extract, or after intravenous administration of either ethanolic extract ${ }^{12}$. Rats treated orally with $800 \mathrm{mg} / \mathrm{kg}$ of crude extract of Peumus boldus and boldine demonstrated anatomical alterations in the fetus and cases of abortive activity ${ }^{26}$. A case is reported in which a several-fold increase in transaminases and g-GT was detected in an elderly male patient with fatty liver in use a laxative with addition of boldo leaf extracts concluding this extracts might be hepatotoxic, at least in elderly patients with fatty liver ${ }^{27}$. On the other hand, lower doses of the same extract, ranging from 20 to $40 \mathrm{mg} / \mathrm{Kg}$, have demonstrated to ameliorate toxicity generated by cisplatin in liver tissue in vivo ${ }^{11}$.

In this study, the damage induced in the liver of rats by hepatectomy was extensive and, due to the little amount of references regarding the use of these extracts in experimental models of hepatic diseases, we decided to try a bit higher dose 
than the ones described by Mondal et al. ${ }^{11}$, but lower than those used by Lanhers et al. ${ }^{12}$ which have failed in previously reported experiments.

Hepatocytes are the main target of studies on liver regeneration, once these cell subsets comprise $90 \%$ of the hepatic weight and approximately $60 \%$ of the total number of cells of the liver ${ }^{10}$. Therefore, in order to evaluate the proliferative activity of hepatocytes we assessed the immunoexpression of Ki-67 nuclear antigen, a protein associated with the cell cycle and essential for DNA synthesis.

In this study, the proliferative index of hepatocytes, assessed by the immunoexpression of Ki-67 positive cells, was significantly increased in the AEPB-treated group, suggesting a possible trophic effect of the extract on the damaged liver tissue. Several factors can influence the replication of hepatocytes, with direct or indirect effects on DNA synthesis, which are called mitogenic and co-mitogenic factors, respectively ${ }^{24,25,28}$. As in this study, leaves-derived extracts of Peumus boldus induced hepatocytes proliferation; it is possible to suggest that this natural product display trophic effects on liver tissue. The precise mechanism underlying the proliferative effect displayed by AEPB is still unclear, but it is possible to suppose a possible relation with the well-established antioxidant properties of the bioactive compounds present in the extract, such as alkaloids and flavonoids ${ }^{8,9,13,29,30}$. However, although we provide evidence of a possible hepatotrophic effect of AEPB, further investigations are still required in order to clarify the biochemical mechanism responsible for such biological activity.

Surprisingly, we found no significant difference in the remaining liver weights after oral administration of AEPB at $100 \mathrm{mg} / \mathrm{Kg}$ in comparison with distilled water administration (vehicle). This apparent paradox might be related to the short timecourse of the experiment ( $24 \mathrm{~h}$ only). Thus, although the number of hepatocytes in the cell cycle (Ki67 positive cells) was clearly increased by the administration of the AEPB, the proliferation of the liver tissue after $24 \mathrm{~h}$ was likely not expressive enough to reflect a massive gain of weight. Biochemical data obtained in this study appear to support this theory, since no difference between groups was observed. Therefore, further studies are necessary to evaluate the effect of such increased proliferative index of the hepatocytes on the liver weight, gross features, histological architectiure and biochemical function in linger-term experimental designs.

\section{Conclusion}

The acute oral administration of leaves-derived aqueous extract of Peumus boldus at $100 \mathrm{mg} / \mathrm{Kg}$ exerts significant positive effect on liver regeneration after $24 \mathrm{~h}$ in rats that underwent $70 \%$ hepatectomy, while maintaining unchanged hepatic function.

\section{References}

1- Toderke EL, Baretta GAP, Gama Filho OP, Matias JEF. Sirolimus influence on hepatectomy-induced liver regeneration in rats. Rev Col Bras Cir. 2014;41(3):203-7. PMID: 25140653.

2- Aguiar LRF, Nassif PAN, Ribas CAPM, Czeczko NG, Ribas MM, Marinho Junior $\mathrm{CH}$, Wendler E. Liver regeneration after partial hepatectomy in rats submitted to post-hepatic portal hypertension. Arq Bras Cir Dig. 2011 Apr/Jun;24(2):144-51. doi: 10.1590/S010267202011000200011.

3- Jin S, Fu Q, Wuyun G, Wuyun T. Management of post-hepatectomy complications. World J Gastroenterol. 2013 Nov 28;19(44):798391. doi: 10.3748/wjg.v19.i44.7983.

4- Wei W, Dirsch O, Mclean AL, Zafarnia S, Schwier M, Dahmen U. Rodent models and imaging techniques to study liver regeneration. Eur Surg Res. 2015;54(3-4):97-113. doi: 10.1159/000368573.

5- Lima SO, Viana Lda C, Santana FR, Zucoloto S, Albuquerque Junior RL, Gomes MZ. Proliferative effect of aqueous extract of Hyptis fructicosa on liver regeneration after partial hepatectomy in rats. Acta Cir Bras. 2012 Jan;27(1):71-5. PMID: 22159442.

6- $\quad$ Yang JY, Wang JS, Liu HB. Fructus polygoni orentalis extract inhibited liver regeneration and proliferation of bone marrow cells of rat after partial hepatectomy. Genet Mol Res. $2015 \mathrm{Jul}$ 13;14(3):7671-9. doi: 10.4238/2015.July.13.12.

7- Mazutti M, Mossi AJ, Cansian RL, Corazza ML, Dariva C, Oliveira JV. Chemical profile and antimicrobial activity of Boldo (Peumus boldus Molina) extracts obtained by compressed carbon dioxide extraction. Braz J Chem Eng. 2008;25(2):427-34. doi: 10.1590/ S0104-66322008000200020.

8- Ruiz ALT, Taffarello D, Souza VHS, Carvalho JE. Pharmacology and toxicology of Peumus boldus and Baccharis genistelloides. Rev Bras Farmacogn. 2008;18(2):295-300. doi: 10.1590/S0102695X2008000200025.

9- Klimaczewisk CV, Saraiva RA, Roos DH, Bolingo NA, Athayde ML, Kamdem J, Barbosa NV, Rocha JBT. Antioxidant activity of Peumus boldus extract and alkaloid boldine against damage induced by $\mathrm{Fe}(\mathrm{II})-$ citrate in rat liver mitochondria in vitro. Ind Crop Prod. 2014;54:240-7. doi: 10.1016/j.indcrop.2013.11.051.

10- Fernandez J, Lagos P, Rivera P, Zamorano-Ponce E. Effect of boldo (Peumus boldus Molina) infusion on lipoperoxidation induced by cisplatin in mice liver. Phytother Res. 2009 Jul;23(7):1024-7. doi: $10.1002 /$ ptr. 2746 .

11- Mondal J, Bishayee K, Panigrahi AK, Khuda-Bukhsh AR. Low doses of ethanolic extract of Boldo (Peumus boldus) can ameliorate toxicity generated by cisplatin in normal liver cells of mice in vivo and in WRL-68 cells in vitro, but not in cancer cells in vivo or in vitro. J Integr Med. 2014 Sep;12(5):425-38. doi: 10.1016/S20954964(14)60045-5.

12- Lanhers MC, Joyeux M, Soulimani R, Fleurentin J, Sayag M, Mortier F, Younos C, Pelt JM. Hepatoprotective and anti-inflammatory effects of a traditional medicinal plant of Chile, Peumus boldus. Planta Med. 1991 Apr;57(2):110-5. doi: 10.1055/s-2006-960043.

13- Simirgiotis MJ, Schmeda-Hirschmann G. Direct identification of phenolic constituents in Boldo Folium (Peumus boldus Mol.) infusions by high-performance liquid chromatography with diode array detection and electrospray ionization tandem mass spectrometry. J Chromatogr A. 2010 Jan 22;1217(4):443-9. doi: 10.1016/j.chroma.2009.11.014.

14- Zagorova M, Prasnicka A, Kadova Z, Dolezelova E, Kazdova 
L, Cermanova J, Rozkydalova L, Hroch M, Mokry J, Micuda S. Boldine attenuates cholestasis associated with nonalcoholic fatty liver disease in hereditary hypertriglyceridemic rats fed by highsucrose diet. Physiol Res. 2015;64 Suppl 4:S467-76. PMID: 26681076.

15- Cermnova J, Kadova Z, Zagorova M, Hroch M, Tomsik P, Nachtigal P, Kudlackova Z. Boldine enhances bile production in rats via osmotic and Farnesoid $\mathrm{X}$ receptor dependent mechanisms. Toxicol Appl Pharmacol. 2015 May 15;285(1):12-22. doi: 10.1016/j. taap.2015.03.004.

16- Zhang M, Xie Z, Gao W, Pu L, Wei J, Guo C. Quercetin regulates hepatic cholesterol metabolism by promoting cholesterol-to-bile acid conversion and cholesterol efflux in rats. Nutr Res. 2016 Mar;36(3):271-9. doi: 10.1016/j.nutres.2015.11.019.

17- Kemelo MK, Horinek A, Canová NK, Farghali H. Comparative effects of Quercetin and SRT1720 against D-galactosamine/ lipopolysaccharideinduced hepatotoxicity in rats: biochemical and molecular biological investigations. Eur Rev Med Pharmacol Sci. 2016;20:363-71. PMID: 26875909.

18- Khan AZ, Mudan SS. Liver regeneration:mechanisms, mysteries and more. ANZ J Surg. 2007 Jan-Feb;77(1-2):9-14. doi: 10.1111/j.14452197.2006.03981.x.

19- Koniaris LG, Mckillop I, Scwartz SI, Zimmers TA. Liver regeneration. J Am Coll Surg. 2003;197(4): 634-48. doi: 10.1016/ S1072-7515(03)00374-0.

20- Rosal MA, Gonçalves WJ, Alves MTS, Baracat EC, Lima GR. Histopathological and immunohistochemical analysis (proliferating cell nuclear antigen) of patients with invasive cervical carcinoma before and after radiotherapy and surgery. Rev Assoc Med Bras (1992). 2002 Jan-Mar;48(1):32-5. PMID: 12185633.

21- Francavilla A, Barone M, Todo S, Zeng QH, Porter KA, Starzl TE. Augmentation of rat liver regeneration by FK506 compared with cyclosporin. Lancet. 1989 Nov 25;2(8674):1248-9. PMID: 2479802.

22- Schemeda-Hirschmann G, Rodriguez JA, Theoduloz C, Astudillo SL, Feresin GE, Tapia A. Free-radical scavengers and antioxidants from Peumus boldus Mol. ('Boldo"). Free Radic Res. 2003 Apr;37(4):447-52. PMID: 12747739.

23- O'Brien P, Carrasco-Poso C, Speisky H. Boldine and its antioxidante or health-promoting properties. Chem Biol Interact. 2006 Jan 5;159(1):1-17. doi: 10.1016/j.cbi.2005.09.002.

24- Bittner N, Aguilera M, Hernández V, Arbert C, Becerra J, Casnueva E. Fungistatic activity of essential oils extracted from Peumus boldus Mol, Laureliopsis philippiana(Looser) Schodde and Laurelia sempervirens(Ruiz \& Pav.) Tul. (Chilean Monimiaceae). Chil J Agric Res. 2009;(69):30-7. doi: 10.4067/S0718-58392009000100004.

25- Falé PL, Amaral F, Amorin MPJ, Souza SM, Florêncio MH, Farzão FN, Serralheiro ML. Acetylcholinesterase inhibition, antioxidant activity and toxicity of Peumus boldus water extracts on HeLa andCaco-2 cell lines. Food Chem Toxicol. 2012 Aug;50(8):265662. doi: 10.1016/j.fct.2012.04.049.

26- Almeida ER, Melo AM, Xavier H. Toxicological evaluation of the hydro-alcohol extract of the dry leaves of Peumus boldus and boldine in rats. Phytother Res. 2000 Mar;14(2):99-102. PMID: 10685105 .

27- Piscaglia F, Leoni S, Venturi A, Graziella F, Donati G, Bolondi L. Caution in the use of boldo in herbal laxatives: a case of hepatotoxicity. Scand J Gastroenterol. 2005 Feb;40(2):236-9. doi: 10.1080/00365520410009537.

28- Lau YS, Tian XY, Mustafa MR, Murugan D, Liu J, Zhang Y, Lau $\mathrm{CW}$, Huang Y. Boldine improves endothelial function in diabetic $\mathrm{db} / \mathrm{db}$ mice through inhibition of angiotensin II-mediated BMP4oxidative stress cascade. Br J Pharmacol. 2013 Nov;170(6):1190-8. doi: $10.1111 / \mathrm{bph} .12350$.
29- Silva RL, Melo GB, Antoniolli AR, Lima SO, Melo VA, Ramalho FS, Ramalho LNZ, Zucoloto S, Silva Júnior OC. Effect of the aqueous extract of Hyptis pectinata on hepatocyte proliferation after partial hepatectomy. Acta Cir Bras. 2002;17(3):101-5. doi: 10.1590/ S0102-86502002000900021.

30- Melo GB, Silva RL, Melo VA, Lima SO, Antaniolli AR, Castro-E Silva T, Marcassa LG, Bagnato VS, Zucoloto S, Ramalho LN, Ramalho FS; Castro-E Silva O Jr. Enhancement of liver regeneration by the association of Hyptis pectinata with laser therapy. Dig Dis Sci. 2005 May;50(5):949-54. PMID: 15906774.

\section{Acknowledgement}

To Sonia Maria Bismarck dos Santos for the support during the execution of surgical procedure in rats.

\section{Correspondence:}

Maria Bernadete Galrão de Almeida Figueiredo

Avenida Beiramar, 1704/801

49025-040 Aracajú-SE Brasil

Tel.: (55 79)99137-0678

gbafigueiredo@gmail.com

Received: May 18, 2016

Review: July 20, 2016

Accepted: Aug 21, 2016

Conflict of interest: none

Financial source: none

${ }^{1}$ Research performed at Bio Laboratory of Morphology and Structural Biology (LMBE), ITP (Research and Technology Institute), Universidade Tiradentes (UNIT), Aracaju-SE, Brazil. 